\title{
Article
}

\section{Alkylative Aziridine Ring-Opening Reactions}

\author{
Jieun Choi, Taehwan Yu and Hyun-Joon Ha *
}

Department of Chemistry, Hankuk University of Foreign Studies, Yongin 17035, Korea; jieun3369@gmail.com (J.C.); sunjew03221@naver.com (T.Y.)

* Correspondence: hjha@hufs.ac.kr; Tel.: +82-31-330-4369

check for updates

Citation: Choi, J.; Yu, T.; Ha, H.-J. Alkylative Aziridine Ring-Opening Reactions. Molecules 2021, 26, 1703. https://doi.org/10.3390/molecules 26061703

Academic Editor: Marek

M. Kowalczuk

Received: 2 March 2021

Accepted: 15 March 2021

Published: 18 March 2021

Publisher's Note: MDPI stays neutral with regard to jurisdictional claims in published maps and institutional affiliations.

Copyright: (c) 2021 by the authors. Licensee MDPI, Basel, Switzerland. This article is an open access article distributed under the terms and conditions of the Creative Commons Attribution (CC BY) license (https:// creativecommons.org/licenses/by/ $4.0 /)$.

\begin{abstract}
In this study, the highly strained three-membered aziridine ring was successfully activated as the aziridinium ion by alkylation of the ring nitrogen with a methyl, ethyl or allyl group, which was followed by ring opening with external nucleophiles such as acetate and azide. Such alkylative aziridine ring opening provides an easy route for the synthesis of various $N$-alkylated aminecontaining molecules with concomitant introduction of an external nucleophile at either its $\alpha$ - or $\beta$-position.
\end{abstract}

Keywords: aziridine; non-activated; aziridinium ion; alkylative; ring-opening; amine; regioselectivity

\section{Introduction}

Aziridine, a nitrogen-containing three-membered ring, has high ring strain similar to oxirane and cyclopropane [1-12]. However, the non-activated aziridine-bearing electron donating group at the ring nitrogen is relatively stable and inert toward almost all nucleophiles. It should be activated properly as an aziridinium ion or its equivalent prior to ring-opening reaction, as shown in Scheme 1 [13,14].

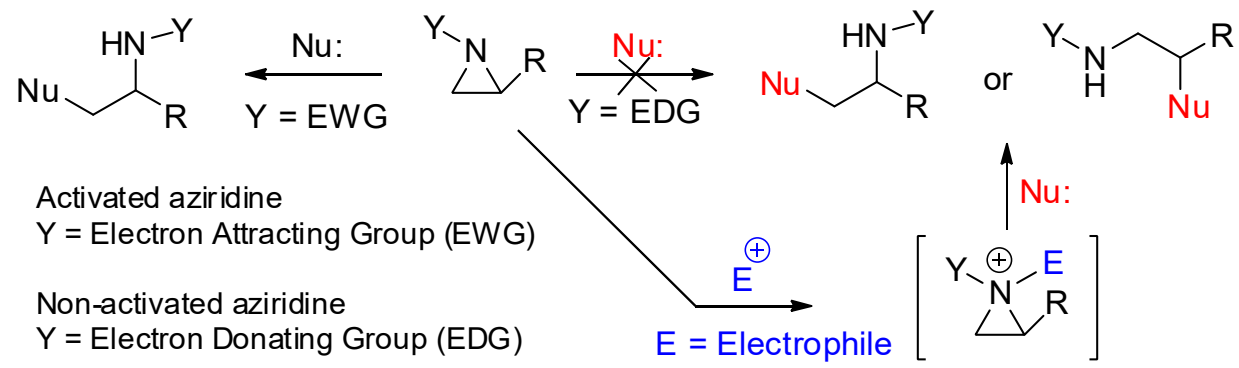

Scheme 1. Nucleophilic ring opening of activated and non-activated aziridines.

The reactivity of non-activated aziridine provides an opportunity to introduce another functional group into the ring nitrogen during activation of the aziridine ring. Electrophiles for the activation of non-activated aziridine by bond formation, including carbon-carbon and carbon-silicon, and by Lewis acid (LA) coordination with lone pair electrons at the aziridine ring nitrogen can yield aziridinium ions or their equivalents [15]. These electrophiles include haloalkanes, acyl halides, trialkylsilyl halides and most Lewis acids [16-19]. However, most aziridinium ions are quite reactive toward the counter anion ( $\mathrm{X}^{-}$in Scheme 2 ) released from reagents of electrophiles as a nucleophile to be broken down [20-24]. Introduction of a specific group with concomitant breakage of the ring opening by an external nucleophile is a challenging problem to be solved to boost the synthetic utility of aziridine. To make this possible, the aziridinium ion should be stable as it is a quaternary ammonium salt enduring the strain of a three-membered aziridine ring until the external nucleophile reacts for ring opening $[25,26]$. It means that the nucleophilicity of the counter anion from the reagent of the electrophile should be weak enough for the aziridinium ion to survive. This is a key requirement for the external nucleophile added to the reaction media that 
leads to ring opening at either its $\alpha$ - or $\beta$-position in a regioselective manner, as shown in Scheme 2.

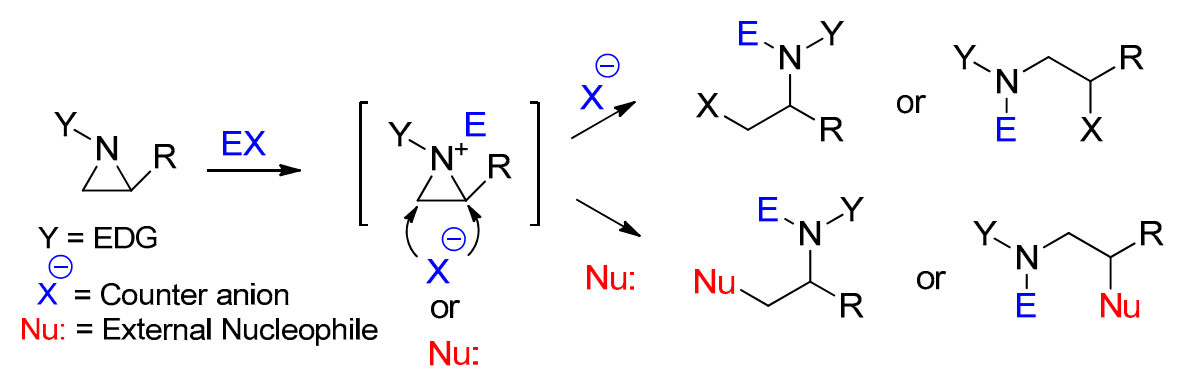

Scheme 2. Aziridine ring opening either by a counter anion $\left(\mathrm{X}^{-}\right)$of an electrophile or by an external nucleophile (Nu:) added directly to the reaction vessel.

\section{Results and Discussion}

Every electrophile provides an aziridinium ion with unique characteristics that leads to ring-opening reactions in distinctive regiochemical pathways; either " $a$ " or " $b$ " in Scheme 3, as summarized in our previous publication [27]. The ring substituent $R$ and the nucleophile $\left(\mathrm{Nu}^{-}\right)$applied in the reaction vessel are also crucial to determine regiochemical pathways $[27,28]$.

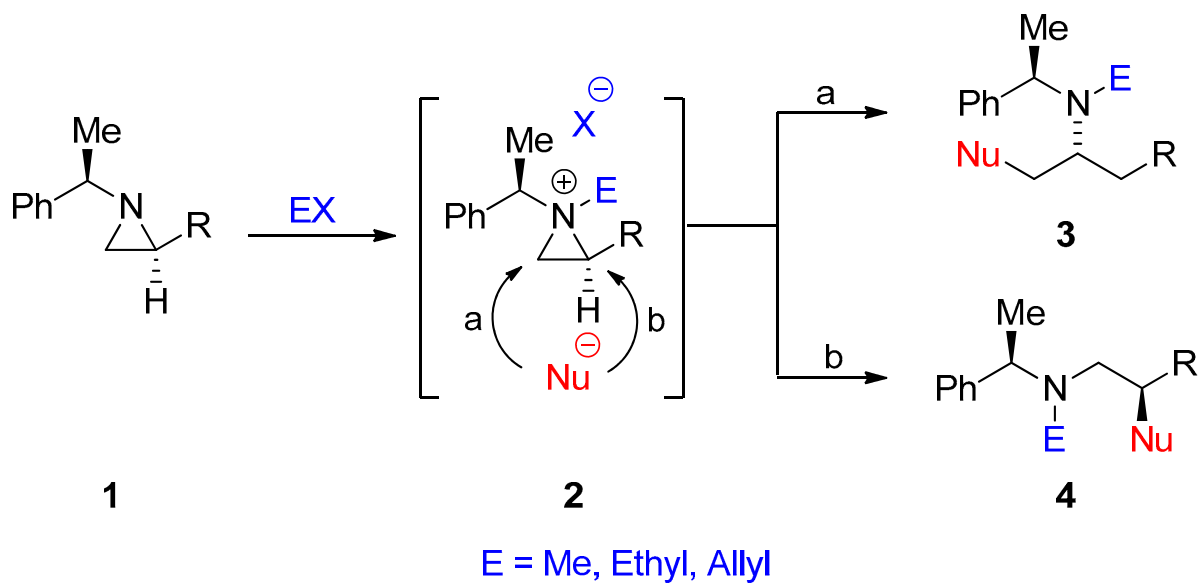

Scheme 3. Aziridine ring opening in either ways " $a$ " or " $b$ ". Activation with an alkyl group from an electrophile (EX) to make the aziridinium ion in the bracket, followed by aziridine ring-opening reactions with an external nucleophile $\left(\mathrm{Nu}^{-}\right)$for alkylative aziridine ring opening.

Our previous study $[27,28]$ showed that the reaction of aziridine (1) bearing a 2methylbenzyl group as an electron-donating group (EDG) at the ring nitrogen with methyl trifluoromethylsulfonate (MeOTf) can provide stable aziridinium ions such as $\mathbf{2}(\mathrm{E}=\mathrm{Me}$, $X=\mathrm{TfO}^{-}$) (Scheme 3). Among all electrophiles applicable to the activation of non-activated aziridine, the alkyl group is a good applicant with numerous advantages. It can provide a good chance to introduce a new alkyl group at the ring nitrogen and nucleophiles either at the $\alpha$ - or $\beta$-carbon of nitrogen, depending on the regiochemical pathways [29-31]. In a previous study, we were able to introduce a methyl group to generate the $N$-methylaziridinium ion and lead to subsequent ring openings for $\mathrm{N}$-methylated acyclic amines in a regio- and stereoselective manner [32]. This new reaction, called the $N$-methylative aziridine ringopening reaction, was used as a key step for the synthesis of various biologically important molecules. We succeeded in making $N$-methylative aziridine ring-opening reactions with methyl group at the nitrogen coming from MeOTf for the formation of aziridinium ions and subsequent ring opening by nucleophiles, including acetate for MeBMT [33]; protected p-hydroxyphenyl magnesium bromide for tyroscherin [34,35]; and nitriles for hygroline, 
pseudohygroline, hygrine [36] and part of PF-00951966 [37] (Figure 1). These examples showed the value of $\mathrm{N}$-methylative aziridine ring-opening reactions.<smiles>C/C=C/CC(C)[C@H](O)[C@H](NC)C(=O)O</smiles>

MeBMT<smiles>CC[C@@H](C)C[C@@H](C)/C=C/CC[C@@H](O)[C@H](Cc1ccc(O)cc1)NC</smiles><smiles>CN[C@@H](CC#N)C1CCN(C(C)(C)C)C1</smiles>

Part of PF-00951966

Figure 1. Biologically important molecules synthesized through $N$-methylative aziridine ring-opening reactions. Methyl groups (Me) shown in blue; nucleophiles shown in red.

Expansion of this reaction with alkylation other than methylation will provide a general route for the synthesis of various alkyl- or functionalized amine-containing molecules. However, there are problems associated with this new reaction that should be overcome for this reaction to be synthetically valuable. At first, the aziridinium ion derived after aziridine is alkylated should be stable enough for the external nucleophiles to be reacted. In other words, the counter anion used to form the aziridinium ion is not nucleophilic enough to break down the intermediate. Instead, an external nucleophile should be reactive enough to give a decent yield of the ring-opening reaction [37]. In addition, the regiochemical pathway should be controllable. It should be either pathway "a" or " $b$ " to yield an $\alpha$ or $\beta$-amino compound selectively. However, up to now, only $N$-methylation has been successful, while all other bigger alkyl groups have been unsuccessful, possibly due to the limitations of the small steric space to accommodate a bigger group under mild reaction conditions. This intrinsic drawback should be overcome by improving the reactivity of the incoming reactant as an electrophile-bearing non-nucleophilic leaving group. After numerous approaches, we finally succeeded in the alkylation of the ring nitrogen, including ethyl and allyl groups besides methyl, to give rise to the corresponding $\mathrm{N}$-alkylated amines after aziridine ring opening.

At first, the ethylative aziridine ring opening was tried using the same protocol used for methylation with MeOTf as the methylating agent and with $\mathrm{TfO}^{-}$as its counter anion. The ethyl group was introduced into the aziridine ring by addition of EtOTf to the substrate, followed by the external nucleophile NaOAc. As expected, the reaction medium $\mathrm{CH}_{3} \mathrm{CN}$ was the best to yield reaction products (3AEa and $4 \mathrm{AEa}$, overall yield: $49 \%$ ) from 2-benzyloxymethylaziridine (1A), with the kinetic product as the major one and regioselectivity of 88:12 in $\mathrm{CH}_{3} \mathrm{CN}$ among many solvents, including DMF, THF, dioxane and $\mathrm{CH}_{2} \mathrm{Cl}_{2}$ (Table 1, entries 1 and 2). With an increase of the nucleophile from 1.1 to 1.5 equiv., the reaction yield was improved from 49 to $62 \%$ (entry 3 ). Instead of the 2benzyloxymethyl group, 2-triethylsilyloxymethyl and 2-t-butyldimethylsilyloxymethyl substitution (1B and 1C) afforded the expected products (3BEa and 4BEA; 3CEa and 4CEA) in slightly better yields (64 and $72 \%$, entries 4 and 5). 
Table 1. Ethylative aziridine ring-opening reactions with EtOTf in $\mathrm{CH}_{3} \mathrm{CN}^{\text {a }}$.

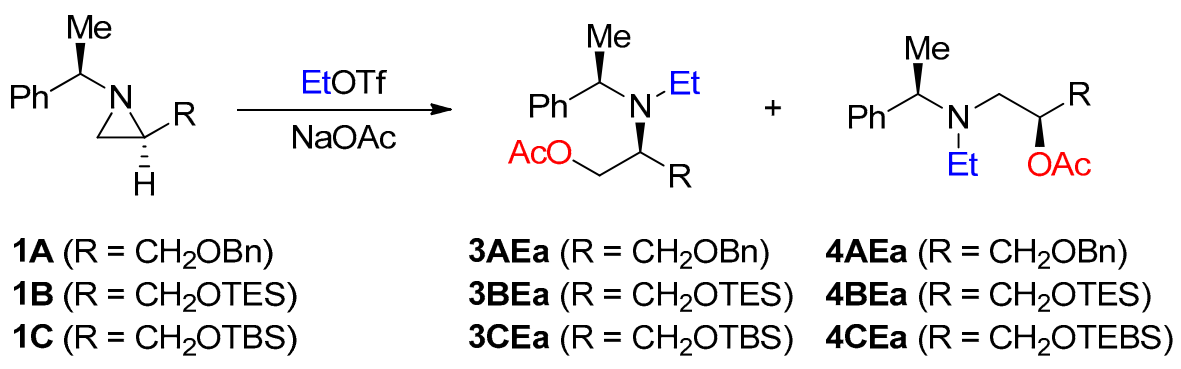

\begin{tabular}{ccccccc}
\hline Entry & $\mathbf{R}$ & MNu (equiv.) & Solvent & Rxn (h) & Yield (\%) & b \\
\hline 1 & $\mathrm{CH}_{2} \mathrm{OBn}$ & $\mathrm{NaOAc}(1.1)$ & $\mathrm{CH}_{3} \mathrm{CN}$ & 6 & $49 \%$ & $88: 12$ \\
2 & $\mathrm{CH}_{2} \mathrm{OBn}$ & $\mathrm{NaOAc}(1.1)$ & $\mathrm{DMF}$ & 12 & $12 \%$ & $62: 38$ \\
3 & $\mathrm{CH}_{2} \mathrm{OBn}$ & $\mathrm{NaOAc}(1.5)$ & $\mathrm{CH}_{3} \mathrm{CN}$ & 6 & $62 \%$ & $96: 4$ \\
4 & $\mathrm{CH}_{2} \mathrm{OTES}$ & $\mathrm{NaOAc}(1.5)$ & $\mathrm{CH}_{3} \mathrm{CN}$ & 12 & $64 \%$ & $96: 4$ \\
5 & $\mathrm{CH}_{2} \mathrm{OTBS}$ & NaOAc (1.5) & $\mathrm{CH}_{3} \mathrm{CN}$ & 12 & $72 \%$ & $84: 16$ \\
\hline
\end{tabular}

a Reaction conditions: aziridine $1(0.374 \mathrm{mmol})$, ethyl trifluoromethanesulfonate $(0.411 \mathrm{mmol}), \mathrm{NaOAc}$ $(0.561 \mathrm{mmol})$ and solvent $(4 \mathrm{~mL})$, under a nitrogen atmosphere. ${ }^{\mathrm{b}}$ Isolated yield.

All numbered compound in Tables 1 and 2 are classified by: (i) the second notation based on the starting substrates: $\mathbf{A}, \mathrm{R}=\mathrm{CH}_{2} \mathrm{OBn} ; \mathbf{B}, \mathrm{R}=\mathrm{CH}_{2} \mathrm{OTES} ; \mathrm{C}, \mathrm{R}=\mathrm{CH}_{2} \mathrm{OTBS}$; $\mathrm{D}, \mathrm{R}=\mathrm{CO}_{2} \mathrm{Et}$; (ii) the third notation based on the alkyl at the nitrogen $\mathrm{N}$ : $\mathrm{E}=$ ethyl; $\mathrm{A}=$ allyl; and (ii) the fourth notation based on the nucleophile at the carbon: $\mathbf{a}=\mathrm{OAc} ; \mathbf{b}=\mathrm{N}_{3}$.

Table 2. Allylative aziridine ring-opening reactions with $\mathrm{ICH}_{2} \mathrm{CHCH}_{2}$ (1.25 equiv.) and AgOTf (1.05 equiv.) in $\mathrm{CH}_{3} \mathrm{CN}^{\mathrm{a}}$.

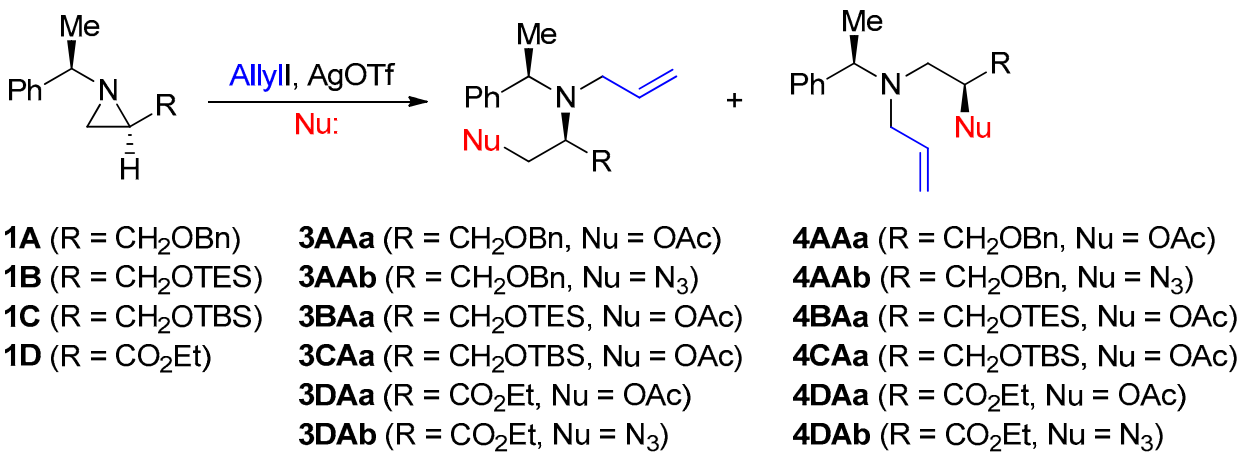

\begin{tabular}{|c|c|c|c|c|c|}
\hline Entry & $\mathbf{R}$ & MNu (Equiv.) & Rxn (h) & Yield $(\%)^{b}$ & $3: 4$ \\
\hline 1 & $\mathrm{CH}_{2} \mathrm{OBn}$ & $\mathrm{NaOAc}(1.5)$ & 8 & $85 \%$ & 50:50 \\
\hline 2 & $\mathrm{CH}_{2} \mathrm{OBn}$ & $\mathrm{NaOAc}(3.0)$ & 8 & $97 \%$ & $43: 57$ \\
\hline 3 & $\mathrm{CH}_{2} \mathrm{OBn}$ & CsOAc (1.5) & 24 & $66 \%$ & $60: 40$ \\
\hline 4 & $\mathrm{CH}_{2} \mathrm{OBn}$ & $\mathrm{BnNH}_{2}(1.1)$ & 24 & - & - \\
\hline 5 & $\mathrm{CH}_{2} \mathrm{OBn}$ & $\mathrm{NaN}_{3}(1.1)$ & 12 & 59 & $50: 50$ \\
\hline 6 & $\mathrm{CH}_{2} \mathrm{OBn}$ & $\mathrm{NaN}_{3}(2.0)$ & 8 & 51 & $50: 50$ \\
\hline 7 & $\mathrm{CH}_{2} \mathrm{OBn}$ & $\mathrm{NaN}_{3}(3.0)$ & 8 & 48 & $50: 50$ \\
\hline 8 & $\mathrm{CH}_{2}$ OTES & $\mathrm{NaOAc}(1.1)$ & 8 & 78 & $99: 1$ \\
\hline 9 & $\mathrm{CH}_{2} \mathrm{OTBS}$ & $\mathrm{NaOAc}(1.1)$ & 8 & 89 & 99:1 \\
\hline 10 & $\mathrm{C}(=\mathrm{O}) \mathrm{OEt}$ & $\mathrm{NaOAc}(1.1)$ & 12 & 68 & $11: 89$ \\
\hline 11 & $\mathrm{C}(=\mathrm{O}) \mathrm{OEt}$ & $\mathrm{NaN}_{3}(1.1)$ & 24 & 34 & $47: 53$ \\
\hline
\end{tabular}

a Reaction conditions: aziridine $1(0.374 \mathrm{mmol})$, allyl iodide $(0.468 \mathrm{mmol})$, AgOTf $(0.393 \mathrm{mmol})$ and solvent $(4 \mathrm{~mL})$ under a nitrogen atmosphere. ${ }^{\mathrm{b}}$ Isolated yield.

Such successful ethylative aziridine ring-opening reactions prompted us to realize the key structural element of calicheamicine [38] (10) starting from (2S)-2-((tertbutyldimethylsilyl)oxy)methyl)-1-((R)-1-phenylethyl)aziridine (5) (Scheme 4). The nucleophile acetate was added to the ethylated aziridinium ion to give rise to the ring-opened product 6 in a $75 \%$ yield. This was then hydrolyzed to free alcohol (7). The $N$-phenylethyl group in 7 was removed by catalytic hydrogenation in the presence of $(\mathrm{Boc})_{2} \mathrm{O}$ to afford 8 , 
followed by the treatment with a base to yield (S)-4-((tert-butyldimethylsilyl)oxy)methyl)3-ethyloxazolidin-2-one (9) [21,39,40], whose silyl group was removed by TBAF to give free alcohol $\left(\mathbf{9}^{\prime}\right)$. Oxidation of alcohol $\left(\mathbf{9}^{\prime}\right)$ by the Swern oxidation protocol gave the expected key structural element (10) for the synthesis of calicheamicine.

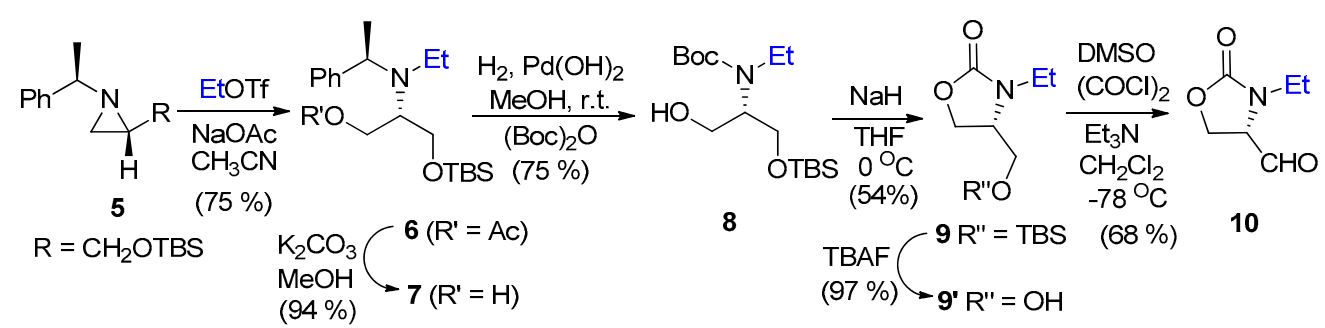

Scheme 4. Synthesis of the key structural element of calicheamicine (10) bearing an ethyl group at the nitrogen from ethylative aziridine ring opening.

This result, including our previous finding, indicates that $\mathrm{TfO}^{-}$is a quite unique counter anion without much nucleophilicity $[25,41]$. Once the ethylative aziridine ring opening has succeeded, it is of interest to add an allyl group, which has an olefin, as a potentially versatile functional group. However, allyl triflate is not stable or readily available when it is needed. The reactions with allyl triflate afforded the reaction product in poor and variable yields. Therefore, we tried to obtain the aziridinium ion with the addition of an allyl group at the ring nitrogen in different ways. Since iodine anion is a reactive nucleophile able to break the aziridine ring and its ring-opened product provides a fast equilibrium back to the aziridinium ion [8], we decided to try with allyl iodide. Thus, we observed that the iodinated product in the possible thermodynamic pathway was obtained very slowly. The reaction was not completed after more than $48 \mathrm{~h}$. At that point, we decided to add AgOTf (1.05 equiv.), the silver of which would capture iodine as AgI, with the soluble triflate anion leaving the counter anion of the aziridinium ion from the allylation of aziridine. We finally found that the allylative aziridinium ion was able to be generated with $\mathrm{ICH}_{2} \mathrm{CHCH}_{2}$ (1.25 equiv.), AgOTf (1.05 equiv.) in $\mathrm{CH}_{3} \mathrm{CN}$ and external nucleophiles for ring opening (Table 2).

The reaction was performed with the starting substrate (1A) bearing a 2-benzyloxymethyl group as $\mathrm{R}$ with AgOTf, allyl iodide and sodium acetate (NaOAc) as an external nucleophile to afford the ring-opened products (3AAa and 4AAa), whose combined yield was increased from $85 \%$ to $97 \%$ by using twice the amount of acetate with comparably poor regioselectivity from 50:50 to 43:57 (Table 2, entries 1 and 2). We also observed a decrease of the reaction yield from 85 to $66 \%$ by using CsOAc instead of $\mathrm{NaOAc}$ (entry 3 ). A neutral amine nucleophile is not active enough to break down the aziridinium ion to give a ring-opening product (entry 4). With $\mathrm{NaN}_{3}$ as the nucleophile, the reaction gave rise to the expected ring-opening products (3AAb and $4 \mathbf{A A b}$ ) without much difference in regiochemistry and reaction yield, depending on the amount of reagents added (Table 2, entries 5-7). Instead of the benzyloxymethyl group, the starting materials (1B and $\mathbf{1 C})$ with triethylsilyloxymethyl and $t$-butyldimethylsilyloxymethyl as substituents at the $\mathrm{C} 2$ of aziridine gave the expected products (3BAa and 4BAa and 3CAa and 4CAa) with yields of $78 \%$ and $89 \%$, respectively, by following the same procedure with NaOAc as a nucleophile (entries 8 and 9). Regioselectivity of both reactions of 99:1 was astonishing, possibly due to the steric difficulty imposed for the nucleophile to approach. We also studied reactions of starting aziridine (1D) bearing ethoxycarbonyl as a substituent at the $\mathrm{C} 2$ of aziridine with $\mathrm{NaOAc}$ and $\mathrm{NaN}_{3}$ (entries 10 and 11). Reactions with $\mathrm{NaOAc}$ and $\mathrm{NaN}_{3}$ resulted in the ring-opened products (3DAa and 4BAa and 3DAb and 4Dab) with yields of $68 \%$ and $34 \%$, respectively, with regioselectivities of $11: 89$ and $47: 53$, showing that the pathway $\mathrm{b}$ in Scheme 3 is more favorable. This regiochemical pathway $b$ is always dominant with starting materials that have vinyl or carbonyl functional groups at the $\mathrm{C} 2$ of aziridine, due to the weakness of the bond between the $\mathrm{N}$ and $\mathrm{C} 2$. 
As a showcase of this chemistry, the allylated aziridine ring-opened product (12) was afforded to take advantage of the olefin at the amine nitrogen (Scheme 5). At first, the starting 2-allyloxydimethylmethylaziridine (11) was prepared by the addition of methyl magnesium bromide to aziridine-2-carboxylate (1D), followed by the allylation of the resultant free hydroxy group with allyl iodide and $\mathrm{NaH}$ as a base. This aziridine (11) was then used for an $N$-allylated aziridine ring-opening reaction with allyl iodide, AgOTf and $\mathrm{NaOAc}$ as a nucleophile to give the product $\mathbf{1 2}$ in a $71 \%$ yield. This reaction product (12) with two allyl olefins was cyclized in the presence of Grubbs' catalyst to yield an eight-membered ring (13). By catalytic hydrogenation in the presence of $(\mathrm{BOc})_{2} \mathrm{O}$, this ring (13) was saturated and the phenylethyl group at the nitrogen was removed to realize a 4-azaoxo heterocycle (14) with valuable functional groups.

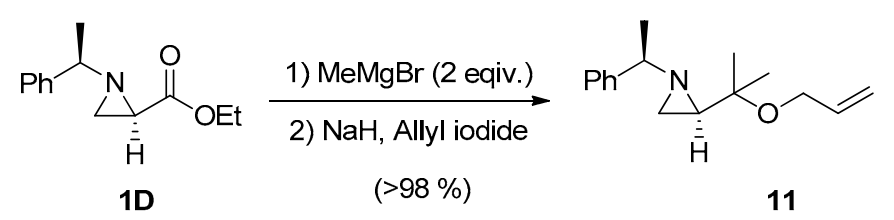

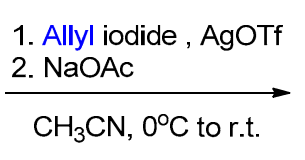

$(71 \%)$

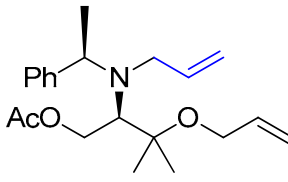

12

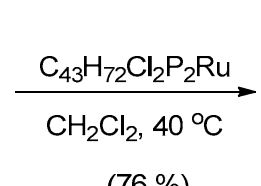

(76\%)
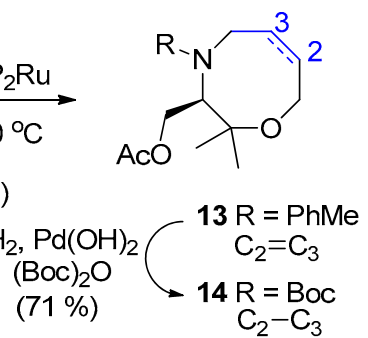

Scheme 5. Synthesis of the unusual eight-membered ring with nitrogen and oxygen at its 1- and 4-positions from the Ring Closing Metathesis of allylated ether and allylated amine from $\mathrm{N}$-allylative aziridine ring opening.

\section{Experimental Section}

\subsection{General Information}

Chiral aziridines are available from Sigma-Aldrich as reagents. They are also available from Imagene Co., Ltd. in bulk quantities. All commercially available compounds were used as received unless stated otherwise. All reactions were carried out under an atmosphere of nitrogen in oven-dried glassware with magnetic stirrer. Dichloromethane was distilled from calcium hydride. Reactions were monitored by thin layer chromatography (TLC) with $0.25 \mathrm{~mm}$ using a Kieselgel 60 Art 9385 from Merck (Darmstadt, Germany. Visualization was accomplished with either UV light or by immersion in solutions of ninhydrin, p-anisaldehyde or phosphomolybdic acid (PMA), followed by heating on a hot plate for about $10 \mathrm{~s}$. Purification of reaction products was carried out by flash chromatography using using a Kieselgel 60 Art 9385 from Merck in Germany. (230-400 mesh). ${ }^{1} \mathrm{H}-\mathrm{NMR}$ and ${ }^{13} \mathrm{C}$-NMR spectra were obtained using a Varian Unity INOVA 400WB $(400 \mathrm{MHz})$ or Bruker AVANCE III HD $(400 \mathrm{MHz})$ spectrometer. Chemical shifts are reported relative to chloroform $(\delta=7.26)$ for ${ }^{1} \mathrm{H}$ NMR, chloroform $(\delta=77.2)$ for ${ }^{13} \mathrm{C}$ NMR, acetonitrile $(\delta=1.94)$ for ${ }^{1} \mathrm{H}$ NMR and acetonitrile $(\delta=1.32)$ for ${ }^{13} \mathrm{C}$ NMR (see Supplementary Materials). Data are reported as $\mathrm{br}=$ broad, $\mathrm{s}=$ singlet, $\mathrm{d}=$ doublet, $\mathrm{t}=$ triplet, $\mathrm{q}=$ quartet, $\mathrm{p}=$ quintet and $\mathrm{m}=$ multiplet. Coupling constants are given in $\mathrm{Hz}$. Ambiguous assignments were resolved using standard one-dimensional proton decoupling experiments. Optical rotations were obtained using a Rudolph Autopol III digital polarimeter and JASCO P-2000. Optical rotation data are reported as follows: $[\alpha]^{20}$ (concentration $c=g / 100 \mathrm{~mL}$, solvent). Highresolution mass spectra were recorded on a 4.7 Tesla IonSpec ESI-TOFMS, JEOL (JMS-700) and an AB Sciex 4800 Plus MALDI TOF ${ }^{\mathrm{TM}}$ (a 2,5-dihydroxybenzoic acid (DHB) matrix was used to prepare samples for MS. Data were obtained in the reflector positive mode with internal standards for calibration). 


\subsection{General Procedure for the Synthesis of Ethylative Aziridine Ring-Opening Compounds}

Ethyl trifluoromethanesulfonate $(0.05 \mathrm{~mL}, 0.411 \mathrm{mmol})$ was added to a stirring solution of aziridine $1(100 \mathrm{mg}, 0.374 \mathrm{mmol})$ in dry $\mathrm{CH}_{3} \mathrm{CN}(4 \mathrm{~mL})$ under $\mathrm{N}_{2}$ at $0{ }^{\circ} \mathrm{C}$. After $5-10 \mathrm{~min}$, $\mathrm{NaOAc}(46 \mathrm{mg}, 0.561 \mathrm{mmol}$ ) was added to the solution at same temperature. After $10 \mathrm{~min}$, the solution was allowed to be warmed to room temperature (RT) and stirred. After quenching by adding water $(10 \mathrm{~mL})$, the reaction product was extracted with $\mathrm{CH}_{2} \mathrm{Cl}_{2}$ $(20 \mathrm{~mL})$ three times. It was then dried over $\mathrm{MgSO}_{4}$, filtered and concentrated in vacuo. The reaction product was purified by column chromatography $(1: 19=$ EtOAc:Hex $)$ to provide an analytically pure product.

\section{3. (S)-3-(benzyloxy)-2-(ethyl((R)-1-phenylethyl)amino)propyl Acetate (3AEa)}

Yellow liquid. $[\alpha]_{\mathrm{D}}{ }^{20} 12.1\left(\mathrm{c}=1.0, \mathrm{CHCl}_{3}\right) .{ }^{1} \mathrm{H}$ NMR $\left(400 \mathrm{MHz}, \mathrm{CDCl}_{3}\right) \delta 7.45-7.10$ $(\mathrm{m}, 10 \mathrm{H}), 4.33(\mathrm{~s}, 2 \mathrm{H}), 4.24(\mathrm{dd}, J=11.2,6.9 \mathrm{~Hz}, 1 \mathrm{H}), 4.14(\mathrm{dd}, J=11.2,5.5 \mathrm{~Hz}, 1 \mathrm{H}), 4.07$ $(\mathrm{d}, J=6.8 \mathrm{~Hz}, 1 \mathrm{H}), 3.35-3.29(\mathrm{~m}, 2 \mathrm{H}), 3.24(\mathrm{~s}, 1 \mathrm{H}), 2.83-2.59(\mathrm{~m}, 2 \mathrm{H}), 2.02(\mathrm{~s}, 3 \mathrm{H}), 1.38(\mathrm{~d}$, $J=6.8 \mathrm{~Hz}, 3 \mathrm{H}), 1.01(\mathrm{t}, J=7.0 \mathrm{~Hz}, 3 \mathrm{H}) .{ }^{13} \mathrm{C} \mathrm{NMR}\left(101 \mathrm{MHz}, \mathrm{CDCl}_{3}\right) \delta 171.10,145.13,138.37$, 128.34, 128.08, 127.59, 127.52, 126.64, 73.07, 69.79, 64.01, 57.80, 55.60, 40.34, 21.13, 19.00, 16.05. HRMS-ESI $(m / z):[\mathrm{M}+\mathrm{H}]^{+}$calcd for $\mathrm{C}_{22} \mathrm{H}_{30} \mathrm{NO}_{3}, 356.2160$, found 356.2162.

\section{4. (S)-1-(benzyloxy)-3-(ethyl((R)-1-phenylethyl)amino)propan-2-yl Acetate (4AEa)}

Yellow liquid. ${ }^{1} \mathrm{H}$ NMR $\left(400 \mathrm{MHz}, \mathrm{CDCl}_{3}\right) \delta 7.41-7.24(\mathrm{~m}, 10 \mathrm{H}), 5.17-5.08(\mathrm{~m}, 1 \mathrm{H})$, $4.54(\mathrm{~d}, J=5.8 \mathrm{~Hz}, 2 \mathrm{H}), 3.88(\mathrm{q}, J=6.8 \mathrm{~Hz}, 1 \mathrm{H}), 3.65(\mathrm{dd}, J=10.7,3.5 \mathrm{~Hz}, 1 \mathrm{H}), 3.59(\mathrm{dd}$, $J=10.7,5.7 \mathrm{~Hz}, 1 \mathrm{H}), 2.72(\mathrm{dd}, J=13.7,7.0 \mathrm{~Hz}, 1 \mathrm{H}), 2.66-2.44(\mathrm{~m}, 3 \mathrm{H}), 2.08(\mathrm{~s}, 3 \mathrm{H}), 1.35(\mathrm{~d}$, $J=6.8 \mathrm{~Hz}, 3 \mathrm{H}), 1.02(\mathrm{t}, J=7.1 \mathrm{~Hz}, 3 \mathrm{H}) .{ }^{13} \mathrm{C} \mathrm{NMR}\left(101 \mathrm{MHz}, \mathrm{CDCl}_{3}\right) \delta 170.58,143.71,138.02$, $128.29,127.96,127.68,126.57,73.03,71.94,69.75,59.04,50.11,44.61,26.43,21.27,16.44,12.80$. HRMS-ESI $(m / z):[\mathrm{M}+\mathrm{H}]^{+}$calcd for $\mathrm{C}_{22} \mathrm{H}_{30} \mathrm{NO}_{3}, 356.2160$, found 356.2162.

\section{5. (R)-2-(ethyl((R)-1-phenylethyl)amino)-3-((triethylsilyl)oxy)propyl Acetate (3BEa)}

Yellow liquid. $[\alpha]_{\mathrm{D}}{ }^{20} 1.1\left(\mathrm{c}=1.0, \mathrm{CHCl}_{3}\right) .{ }^{1} \mathrm{H} \mathrm{NMR}\left(400 \mathrm{MHz}, \mathrm{CDCl}_{3}\right) \delta 7.38(\mathrm{~d}$, $J=7.3 \mathrm{~Hz}, 2 \mathrm{H}), 7.33-7.25(\mathrm{~m}, 2 \mathrm{H}), 7.24-7.18(\mathrm{~m}, 1 \mathrm{H}), 4.23(\mathrm{dd}, J=11.2,7.0 \mathrm{~Hz}, 1 \mathrm{H}), 4.16$ $(\mathrm{dd}, J=11.2,5.4 \mathrm{~Hz}, 1 \mathrm{H}), 4.09(\mathrm{q}, J=6.8 \mathrm{~Hz}, 1 \mathrm{H}), 3.43(\mathrm{~d}, J=6.3 \mathrm{~Hz}, 2 \mathrm{H}), 3.12-2.96(\mathrm{~m}, 1 \mathrm{H})$, $2.77(\mathrm{dd}, J=13.8,7.0 \mathrm{~Hz}, 1 \mathrm{H}), 2.68(\mathrm{dd}, J=13.9,7.0 \mathrm{~Hz}, 1 \mathrm{H}), 2.06(\mathrm{~s}, 3 \mathrm{H}), 1.37(\mathrm{~d}, J=6.8 \mathrm{~Hz}$, $3 \mathrm{H}), 1.02(\mathrm{t}, J=7.0 \mathrm{~Hz}, 3 \mathrm{H}), 0.88(\mathrm{dd}, J=9.5,6.4 \mathrm{~Hz}, 9 \mathrm{H}), 0.48(\mathrm{q}, J=7.9 \mathrm{~Hz}, 6 \mathrm{H}) .{ }^{13} \mathrm{C}$ NMR $\left(101 \mathrm{MHz} \mathrm{CDCl}_{3}\right) \delta 170.98,145.02,138.25,128.22,127.96,127.47,126.52,77.32,77.00,76.68$, $72.95,69.67,63.89,57.68,55.48,40.22,21.02,18.88,15.93$. HRMS-ESI $(m / z):[\mathrm{M}+\mathrm{H}]^{+}$calcd for $\mathrm{C}_{21} \mathrm{H}_{38} \mathrm{NO}_{3} \mathrm{Si}, 380.2512$, found 380.2515 .

\section{6. (S)-1-(ethyl((R)-1-phenylethyl)amino)-3-((triethylsilyl)oxy)propan-2-yl Acetate (4BEa)}

Yellow liquid. ${ }^{1} \mathrm{H}$ NMR $\left(400 \mathrm{MHz} \mathrm{CDCl}_{3}\right) \delta 7.36-7.17(\mathrm{~m}, 5 \mathrm{H}), 4.94(\mathrm{dd}, \mathrm{J}=5.9,3.9 \mathrm{~Hz}$, $1 \mathrm{H}), 3.87(\mathrm{~d}, \mathrm{~J}=6.8 \mathrm{~Hz}, 1 \mathrm{H}), 3.74(\mathrm{dd}, \mathrm{J}=11.1,3.7 \mathrm{~Hz}, 1 \mathrm{H}), 3.66(\mathrm{dd}, \mathrm{J}=11.1,5.7 \mathrm{~Hz}, 1 \mathrm{H})$, $2.66(\mathrm{~d}, \mathrm{~J}=6.6 \mathrm{~Hz}, 1 \mathrm{H}), 2.56(\mathrm{~d}, \mathrm{~J}=7.0 \mathrm{~Hz}, 1 \mathrm{H}), 2.52-2.37(\mathrm{~m}, 2 \mathrm{H}), 2.03(\mathrm{~s}, 3 \mathrm{H}), 1.34(\mathrm{~d}$, $\mathrm{J}=6.8 \mathrm{~Hz}, 3 \mathrm{H}), 1.25(\mathrm{~s}, 1 \mathrm{H}), 1.00(\mathrm{t}, \mathrm{J}=7.1 \mathrm{~Hz}, 3 \mathrm{H}), 0.94(\mathrm{t}, \mathrm{J}=7.9 \mathrm{~Hz}, 9 \mathrm{H}), 0.58(\mathrm{q}, \mathrm{J}=8.0 \mathrm{~Hz}$, 6H). ${ }^{13} \mathrm{C} \mathrm{NMR}\left(101 \mathrm{MHz}, \mathrm{CDCl}_{3}\right) \delta 173.02,170.59,143.71,138.03,128.29,127.90,127.61$, $126.57,77.32,77.00,76.68,73.04,71.94,69.75,59.12,50.11,44.61,39.90,26.37,21.27,16.44$, 12.80. HRMS-ESI $(m / z):[\mathrm{M}+\mathrm{H}]^{+}$calcd for $\mathrm{C}_{21} \mathrm{H}_{38} \mathrm{NO}_{3} \mathrm{Si}, 380.2512$, found 380.2515.

\section{7. (S)-2-(((tert-butyldimethylsilyl)oxy)methyl)-1-((R)-1-phenylethyl)aziridine (5)}

To a stirred solution of ((S)-1-((R)-1-phenylethyl)aziridin-2-yl)methanol (3.191 g, 18.016 mmol) in $\mathrm{CH}_{2} \mathrm{Cl}_{2}(40 \mathrm{~mL})$ at $0{ }^{\circ} \mathrm{C}$ under an inert atmosphere of $\mathrm{N}_{2}$ was added t-butyldimethylsilyl chloride (4.073 $\mathrm{mg}, 24.024 \mathrm{mmol}$ ) and DMAP (4.402 g, $36.032 \mathrm{mmol})$. The mixture was stirred for $5 \mathrm{~min}$ and then warmed to RT. After stirring for $6 \mathrm{~h}$ at RT, the mixture was treated with saturated aqueous $\mathrm{NaHCO}_{3}$ solution. The organic layer was separated and the aqueous layer was extracted with $\mathrm{CH}_{2} \mathrm{Cl}_{2}(25 \mathrm{~mL} \times 2)$. Combined organic extracts were washed with $10 \mathrm{~mL}$ of brine, dried over anhydrous $\mathrm{MgSO}_{4}$, filtered and concentrated in vacuo. The residue was purified by flash column chromatography on silica gel (EtOAc:hexanes $=1: 3$ ) 
to afford a pure product $5(4.997 \mathrm{~g}, 95.2 \%)$. Yellow liquid. $[\alpha]_{\mathrm{D}}{ }^{20}+25.7\left(\mathrm{c}=1.05, \mathrm{CHCl}_{3}\right)$. ${ }^{1} \mathrm{H}$ NMR $\left(400 \mathrm{MHz}, \mathrm{CDCl}_{3}\right) \delta 7.47-7.14(\mathrm{~m}, 5 \mathrm{H}), 3.61(\mathrm{dd}, J=10.9,5.6 \mathrm{~Hz}, 1 \mathrm{H}), 3.44(\mathrm{dd}$, $J=10.9,5.9 \mathrm{~Hz}, 1 \mathrm{H}), 2.49(\mathrm{q}, J=6.6 \mathrm{~Hz}, 1 \mathrm{H}), 1.79(\mathrm{~d}, J=3.4 \mathrm{~Hz}, 1 \mathrm{H}), 1.67(\mathrm{dd}, J=6.1,3.4$ $\mathrm{Hz}, 1 \mathrm{H}), 1.45(\mathrm{t}, J=7.1 \mathrm{~Hz}, 4 \mathrm{H}), 0.84(\mathrm{~s}, 9 \mathrm{H}),-0.01(\mathrm{~d}, J=3.3 \mathrm{~Hz}, 6 \mathrm{H}) .{ }^{13} \mathrm{C} \mathrm{NMR}(101 \mathrm{MHz}$, $\left.\mathrm{CDCl}_{3}\right) \delta 144.42,128.17,126.80,126.65,69.52,65.71,39.97,32.52,25.79,23.08,18.23,-5.41$.

\section{8. (S)-3-((tert-butyldimethylsilyl)oxy)-2-(ethyl((R)-1-phenylethyl)amino)propyl Acetate (6)}

To a stirred solution of (S)-2-(((tert-butyldimethylsilyl)oxy)methyl)-1-((R)-1-phenylethyl)aziridine (5) $(0.500 \mathrm{~g}, 1.717 \mathrm{mmol})$ in dry $\mathrm{CH}_{3} \mathrm{CN}(5.72 \mathrm{~mL})$ was added ethyl trifluoromethanesulfonate $(0.244 \mathrm{~mL}, 1.889 \mathrm{mmol})$ under $\mathrm{N}_{2}$ at $0{ }^{\circ} \mathrm{C}$. After 5-10 min, NaOAc $(0.154 \mathrm{~g}, 1.889 \mathrm{mmol})$ was added to the solution at the same temperature. After $10 \mathrm{~min}$, the solution was allowed to be warmed to RT and was stirred for $12 \mathrm{~h}$. Then, it was quenched by adding water $(10 \mathrm{~mL})$. The reaction product was extracted with $\mathrm{CH}_{2} \mathrm{Cl}_{2}(20 \mathrm{~mL})$ three times. It was then dried over anhydrous $\mathrm{MgSO}_{4}$, filtered and concentrated in vacuo. The reaction product was purified by column chromatography $(1: 19=$ EtOAc:Hex $)$ to provide an analytically pure product $6(0.411 \mathrm{~g}, 75 \%)$. Yellow liquid. $[\alpha]_{\mathrm{D}}{ }^{20}-6.7\left(\mathrm{c}=1.1, \mathrm{CHCl}_{3}\right)$. ${ }^{1} \mathrm{H} \mathrm{NMR}\left(400 \mathrm{MHz}, \mathrm{CDCl}_{3}\right) \delta 7.44(\mathrm{~d}, J=7.3 \mathrm{~Hz}, 2 \mathrm{H}), 7.34(\mathrm{dd}, J=10.2,4.8 \mathrm{~Hz}, 2 \mathrm{H})$, $7.28-7.20(\mathrm{~m}, 1 \mathrm{H}), 4.17(\mathrm{~d}, J=6.8 \mathrm{~Hz}, 1 \mathrm{H}), 4.12(\mathrm{dd}, J=6.4,2.1 \mathrm{~Hz}, 2 \mathrm{H}), 3.79(\mathrm{dd}, J=10.2$, $5.4 \mathrm{~Hz}, 1 \mathrm{H}), 3.72(\mathrm{dd}, J=10.3,6.1 \mathrm{~Hz}, 1 \mathrm{H}), 3.24-2.98(\mathrm{~m}, 1 \mathrm{H}), 2.84-2.77(\mathrm{~m}, 2 \mathrm{H}), 2.03(\mathrm{~s}, 3 \mathrm{H})$, $1.45(\mathrm{~d}, J=6.8 \mathrm{~Hz}, 3 \mathrm{H}), 1.07(\mathrm{t}, J=7.1 \mathrm{~Hz}, 3 \mathrm{H}), 0.96(\mathrm{~s}, 9 \mathrm{H}), 0.10(\mathrm{~d}, J=4.9 \mathrm{~Hz}, 6 \mathrm{H}) .{ }^{13} \mathrm{C}$ NMR $\left(101 \mathrm{MHz} \mathrm{CDCl}_{3}\right) \delta 170.78,145.62,128.01,127.55,126.49,63.53,62.70,57.69,40.35$, $25.94,21.01,18.65,18.22,16.13,-5.54$. HRMS-ESI $(m / z):[\mathrm{M}+\mathrm{H}]^{+}$calcd for $\mathrm{C}_{21} \mathrm{H}_{38} \mathrm{NO}_{3} \mathrm{Si}$, 380.2531 , found 380.2534 .

\section{9. (S)-3-((tert-butyldimethylsilyl)oxy)-2-(ethyl((R)-1-phenylethyl)amino)propan-1-ol (7)}

To a stirred solution of (S)-3-((tert-butyldimethylsilyl)oxy)-2-(ethyl((R)-1-phenylethyl)amino)propyl acetate $(6)(1.30 \mathrm{~g}, 3.428 \mathrm{mmol})$ in $\mathrm{MeOH}(10 \mathrm{~mL})$ at $0{ }^{\circ} \mathrm{C}$ under an inert atmosphere of $\mathrm{N}_{2}$ was added potassium carbonate $(0.710 \mathrm{~g}, 5.142 \mathrm{mmol})$. The mixture was stirred for $10 \mathrm{~min}$. The mixture was further stirred for $3 \mathrm{~h}$ at RT and was treated with saturated aqueous $\mathrm{NaHCO}_{3}$ solution. The organic layer was separated and the aqueous layer was extracted with $\mathrm{CH}_{2} \mathrm{Cl}_{2}(25 \mathrm{~mL} \times 2)$. Combined organic extracts were washed with $10 \mathrm{~mL}$ of brine, dried over anhydrous $\mathrm{MgSO}_{4}$, filtered and concentrated in vacuo. The residue was purified by flash column chromatography on silica gel (EtOAc:hexanes $=1: 3$ ) to afford a pure product $7(0.841 \mathrm{~g}, 94 \%)$. Yellow liquid. $[\alpha]_{\mathrm{D}}{ }^{20}-53.0\left(\mathrm{c}=1.05, \mathrm{CHCl}_{3}\right)$. ${ }^{1} \mathrm{H} \mathrm{NMR}\left(400 \mathrm{MHz}, \mathrm{CDCl}_{3}\right) \delta 7.43-7.18(\mathrm{~m}, 5 \mathrm{H}), 4.14(\mathrm{q}, J=6.8 \mathrm{~Hz}, 1 \mathrm{H}), 3.78(\mathrm{dd}, J=10.3$, $5.3 \mathrm{~Hz}, 1 \mathrm{H}), 3.64-3.46(\mathrm{~m}, 2 \mathrm{H}), 3.33(\mathrm{t}, J=10.0 \mathrm{~Hz}, 1 \mathrm{H}), 3.15-3.02(\mathrm{~m}, 1 \mathrm{H}), 2.90(\mathrm{~s}-\mathrm{br}, 1 \mathrm{H})$, $2.70(\mathrm{q}, J=7.2 \mathrm{~Hz}, 2 \mathrm{H}), 1.42(\mathrm{~d}, J=6.8 \mathrm{~Hz}, 3 \mathrm{H}), 1.00(\mathrm{t}, J=7.1 \mathrm{~Hz}, 3 \mathrm{H}), 0.89(\mathrm{~s}, 9 \mathrm{H}), 0.05$ (s, 6H). ${ }^{13} \mathrm{C}$ NMR $\left(101 \mathrm{MHz}, \mathrm{CDCl}_{3}\right) \delta 144.94,128.29,127.37,126.81,62.13,60.14,59.32,56.51$, $39.51,25.75,18.25,17.36,15.45,-5.59$. HRMS-ESI $(m / z):[\mathrm{M}+\mathrm{H}]^{+}$calcd for $\mathrm{C}_{19} \mathrm{H}_{36} \mathrm{NO}_{2} \mathrm{Si}$, 338.2402, found 338.2405.

\subsection{0. (S)-tert-butyl (1-((tert-butyldimethylsilyl)oxy)-3-hydroxypropan-2-yl)(ethyl)-carbamate (8)}

To a stirred solution of (S)-3-((tert-butyldimethylsilyl)oxy)-2-(ethyl((R)-1-phenylethyl)amino)propyl acetate (7) $(1.130 \mathrm{~g} 2.9980 \mathrm{mmol})$ in $\mathrm{MeOH}(12 \mathrm{~mL})$ was added $\mathrm{Pd}(\mathrm{OH})_{2}$ (0.052 $\mathrm{g}, 50 \%$ wet) and di-tert-butyl dicarbonate $(0.975 \mathrm{~g}, 4.469 \mathrm{mmol})$ at RT under $\mathrm{H}_{2}$. After the reaction was completed, the reaction mixture was filtered with methanol and then concentrated in vacuo. The residue was purified by flash column chromatography on silica gel to afford the pure product $8(0.612 \mathrm{~g}, 75 \%)$. Yellow liquid. $[\alpha]_{\mathrm{D}}{ }^{20} 3.1\left(\mathrm{c}=1.0, \mathrm{CHCl}_{3}\right)$. ${ }^{1} \mathrm{H} \mathrm{NMR}\left(400 \mathrm{MHz}, \mathrm{CDCl}_{3}\right) \delta 3.96(\mathrm{~d}, J=7.3 \mathrm{~Hz}, 1 \mathrm{H}), 3.89-3.79(\mathrm{~m}, 3 \mathrm{H}), 3.75(\mathrm{~s}, 1 \mathrm{H}), 3.60$ $(\mathrm{s}, 1 \mathrm{H}), 3.36-3.29(\mathrm{~m}, 1 \mathrm{H}), 3.25-3.05(\mathrm{~m}, 1 \mathrm{H}), 1.46(\mathrm{~s}, 9 \mathrm{H}), 1.12(\mathrm{t}, J=6.8 \mathrm{~Hz}, 3 \mathrm{H}), 0.89(\mathrm{~s}$, 9H), 0.06 (s, 6H). $\left.{ }^{13} \mathrm{C} \mathrm{NMR} \mathrm{(101} \mathrm{MHz,} \mathrm{CDCl}_{3}\right) \delta 171.06,79.64,63.17,61.83,60.31,43.08$, 28.33, 25.72, 20.93, 18.09, 14.06, -5.60. HRMS-ESI $(m / z):[\mathrm{M}+\mathrm{H}]^{+}$calcd for $\mathrm{C}_{16} \mathrm{H}_{36} \mathrm{NO}_{4} \mathrm{Si}$, 334.2310 , found 380.2313 . 


\subsection{1. (S)-4-((tert-butyldimethylsilyl)oxy)methyl)-3-ethyloxazolidin-2-one (9)}

To a stirred solution of (S)-3-((tert-butyldimethylsilyl)oxy)-2-(ethylamino)propan-1-ol (8) $(0.424 \mathrm{~g}, 1.818 \mathrm{mmol})$ in dry THF $(9.09 \mathrm{~mL})$ was added NaH $(52 \mathrm{mg}, 0.455 \mathrm{mmol})$ under $\mathrm{N}_{2}$ at $0{ }^{\circ} \mathrm{C}$, and after $1 \mathrm{~h}$, was quenched by adding water $(10 \mathrm{~mL})$. The reaction product was extracted with $\mathrm{CH}_{2} \mathrm{Cl}_{2}(50 \mathrm{~mL})$ three times. Then, it was dried over anhydrous $\mathrm{MgSO}_{4}$, filtered and concentrated in vacuo. The reaction product was purified by column chromatography to provide an analytically pure product $9(0.185 \mathrm{~g}, 54 \%)$. Yellow liquid. $[\alpha]_{\mathrm{D}}{ }^{20}-1.7\left(\mathrm{c}=1.05, \mathrm{CHCl}_{3}\right) .{ }^{1} \mathrm{H} \mathrm{NMR}\left(400 \mathrm{MHz}, \mathrm{CDCl}_{3}\right) \delta 4.23(\mathrm{ddd}, J=13.8,6.4,4.6 \mathrm{~Hz}$, $1 \mathrm{H}), 4.00(\mathrm{ddd}, J=10.7,6.9,5.2 \mathrm{~Hz}, 1 \mathrm{H}), 3.81(\mathrm{dd}, J=8.5,4.2 \mathrm{~Hz}, 1 \mathrm{H}), 3.69-3.53(\mathrm{~m}, 2 \mathrm{H})$, 3.52-3.35 (m, 1H), $3.08(\mathrm{ddd}, J=6.6,5.9,3.2 \mathrm{~Hz}, 1 \mathrm{H}), 1.13-1.00(\mathrm{~m}, 3 \mathrm{H}), 0.79(\mathrm{~s}, 9 \mathrm{H}),-0.01$ (s, 6H). ${ }^{13} \mathrm{C} \mathrm{NMR}\left(101 \mathrm{MHz}, \mathrm{CDCl}_{3}\right) \delta 157.99,77.89,77.16,76.69,64.29,62.20,55.60,36.87$, $25.43,17.79,12.62,-5.83$. HRMS-ESI $(m / z)$ : $[\mathrm{M}+\mathrm{H}]^{+}$calcd for $\mathrm{C}_{12} \mathrm{H}_{26} \mathrm{NO}_{3} \mathrm{Si}, 260.1605$, found 260.1607 .

\subsection{2. (R)-3-ethyl-4-(hydroxymethyl)oxazolidin-2-one (9')}

To a stirred solution of (S)-4-(((tert-butyldimethylsilyl)oxy)methyl)-3-ethyloxazolidin2-one (9) $(0.543 \mathrm{~g}, 2.095 \mathrm{mmol})$ in dry THF $(6.98 \mathrm{~mL})$ at $0{ }^{\circ} \mathrm{C}$ was added TBAF $(2.304 \mathrm{~mL}$ $1.0 \mathrm{M}$ in THF, $2.305 \mathrm{mmol}$ ) and reaction mixture was stirred for $3 \mathrm{~h}$. Reaction mixture was quenched with saturated $\mathrm{NH}_{4} \mathrm{Cl}$ solution and then it was extracted with EtOAc $(3 \times 10 \mathrm{~mL})$. Combined organic layer was dried over anhydrous $\mathrm{Mg}_{2} \mathrm{SO}_{4}$. The reaction product was purified by column chromatography $(1: 9=$ methanol:ethyl acetate $)$ to provide an analytically pure product $9^{\prime}(0.294 \mathrm{~g}, 97 \%)$. Yellow liquid. $[\alpha]_{\mathrm{D}}{ }^{20} 40.5\left(\mathrm{c}=1.0, \mathrm{CHCl}_{3}\right)$. ${ }^{1} \mathrm{H}$ NMR $\left(400 \mathrm{MHz}, \mathrm{CDCl}_{3}\right) \delta 4.39(\mathrm{t}, J=8.9 \mathrm{~Hz}, 1 \mathrm{H}), 4.26(\mathrm{dd}, J=8.7,5.9 \mathrm{~Hz}, 1 \mathrm{H}), 4.02-3.89$ $(\mathrm{m}, 1 \mathrm{H}), 3.86-3.81(\mathrm{~m}, 1 \mathrm{H}), 3.76-3.64(\mathrm{~m}, 1 \mathrm{H}), 3.62-3.53(\mathrm{~m}, 1 \mathrm{H}), 3.25-3.17(\mathrm{~m}, 1 \mathrm{H}), 1.21$ $(\mathrm{t}, J=7.2 \mathrm{~Hz}, 3 \mathrm{H}) .{ }^{13} \mathrm{C} \mathrm{NMR}\left(101 \mathrm{MHz}, \mathrm{CDCl}_{3}\right) \delta 158.68,64.65,60.48,55.69,36.70,12.42$. HRMS-ESI $(m / z):[\mathrm{M}+\mathrm{H}]^{+}$calcd for $\mathrm{C}_{6} \mathrm{H}_{12} \mathrm{NO}_{3}, 146.0724$, found 146.0726 .

\subsection{3. (S)-3-ethyl-2-oxooxazolidine-4-carbaldehyde (10)}

To a stirred dimethyl sulfoxide $(0.244 \mathrm{~mL}, 3.447 \mathrm{mmol})$ in dry $\mathrm{CH}_{2} \mathrm{Cl}_{2}(4.60 \mathrm{~mL})$ was added oxalyl chloride $(0.141 \mathrm{~mL}, 1.654 \mathrm{mmol})$ under $\mathrm{N}_{2}$ at $-78^{\circ} \mathrm{C}$. The reaction mixture was stirred for $1 \mathrm{~h}$. Then, (R)-3-ethyl-4-(hydroxymethyl)oxazolidin-2-one (9') $(0.200 \mathrm{~g}$, $1.379 \mathrm{mmol}$ ) was added to the solution under the same condition. After $1 \mathrm{~h}$, triethylamine $(0.576 \mathrm{~mL}, 4.136 \mathrm{mmol})$ was added and stirred for $40 \mathrm{~min}$. After quenching the reaction, the reaction product was extracted with $\mathrm{CH}_{2} \mathrm{Cl}_{2}(3 \times 10 \mathrm{~mL})$. Combined organic layer was dried over $\mathrm{Na}_{2} \mathrm{SO}_{4}$. The reaction product was purified by column chromatography (2:1 $=$ ethyl acetate:hexane) to provide an analytically pure product $10(0.134 \mathrm{~g}, 68 \%)$. Yellow liquid. ${ }^{1} \mathrm{H}$ NMR $\left(400 \mathrm{MHz}, \mathrm{CDCl}_{3}\right) \delta 9.68(\mathrm{~d}, J=0.7 \mathrm{~Hz}, 1 \mathrm{H}), 3.94-3.90(\mathrm{~m}, 1 \mathrm{H}), 3.84-3.79$ $(\mathrm{m}, 1 \mathrm{H}), 3.74-3.65(\mathrm{~m}, 1 \mathrm{H}), 3.60-3.51(\mathrm{~m}, 1 \mathrm{H}), 3.24-3.15(\mathrm{~m}, 1 \mathrm{H}), 1.19(\mathrm{t}, J=7.2 \mathrm{~Hz}, 3 \mathrm{H}) .{ }^{13} \mathrm{C}$ NMR $\left(101 \mathrm{MHz}, \mathrm{CDCl}_{3}\right) \delta 197.22,158.67,64.65,55.68,36.70,12.42$. HRMS-ESI $(m / z):[\mathrm{M}+$ $\mathrm{H}]^{+}$calcd for $\mathrm{C}_{6} \mathrm{H}_{10} \mathrm{NO}_{3}, 144.0612$, found 144.0615.

\subsection{General Procedure for the Synthesis of Allylative Aziridine Ring Opening Compounds}

Silver trifluoromethanesulfonate $(0.07 \mathrm{~g}, 0.393 \mathrm{mmol})$ and allyl iodide $(0.05 \mathrm{~mL}$, $0.468 \mathrm{mmol})$ were added to a stirring solution of aziridine $1(100 \mathrm{mg}, 0.374 \mathrm{mmol})$ in dry $\mathrm{CH}_{3} \mathrm{CN}(4 \mathrm{~mL})$ under $\mathrm{N}_{2}$ at $0{ }^{\circ} \mathrm{C}$. After 5-10 min, nucleophile (1.1 equiv.) was added to the solution at same condition. After $10 \mathrm{~min}$, the solution was allowed to be warmed to RT and was stirred. After quenching by adding water $(10 \mathrm{~mL})$, the reaction product was extracted with $\mathrm{CH}_{2} \mathrm{Cl}_{2}(20 \mathrm{~mL})$ three times. It was then dried over anhydrous $\mathrm{MgSO}_{4}$, filtered and concentrated in vacuo. The reaction product was purified by column chromatography (1:19 = ethyl acetate:hexane) to provide an analytically pure product.

\subsection{5. (S)-2-(allyl((R)-1-phenylethyl)amino)-3-(benzyloxy)propyl Acetate (3AAa)}

Yellow liquid. $[\alpha]_{\mathrm{D}}{ }^{20} 19.4\left(\mathrm{c}=1.0, \mathrm{CHCl}_{3}\right){ }^{1} \mathrm{H} \mathrm{NMR}\left(400 \mathrm{MHz}, \mathrm{CDCl}_{3}\right) \delta 7.42-7.07(\mathrm{~m}$, $10 \mathrm{H}), 5.97-5.69(\mathrm{~m}, 1 \mathrm{H}), 5.17(\mathrm{dd}, J=17.2,1.7 \mathrm{~Hz}, 1 \mathrm{H}), 5.04(\mathrm{dd}, J=10.1,1.6 \mathrm{~Hz}, 1 \mathrm{H}), 4.30(\mathrm{~s}$, 
2H), 4.28-4.19 (m, 1H), 4.19-4.02 (m, 2H), $3.36(\mathrm{dd}, J=15.2,6.0 \mathrm{~Hz}, 1 \mathrm{H}), 3.31-3.20(\mathrm{~m}, 4 \mathrm{H})$, $2.00(\mathrm{~s}, 3 \mathrm{H}), 1.36(\mathrm{~d}, J=6.9 \mathrm{~Hz}, 3 \mathrm{H}) .{ }^{13} \mathrm{C} \mathrm{NMR}\left(101 \mathrm{MHz}, \mathrm{CDCl}_{3}\right) \delta 170.74,144.23,138.72$, $138.09,128.02,127.91,127.38,126.53,115.64,72.84,69.29,63.58,57.53,54.99,49.51,20.90$, 18.59. HRMS-ESI $(m / z):[\mathrm{M}+\mathrm{H}]^{+}$calcd for $\mathrm{C}_{23} \mathrm{H}_{30} \mathrm{NO}_{3}, 368.2102$, found 368.2106.

3.16. (S)-2-(allyl((R)-1-phenylethyl)amino)-3-((tert-butyldimethylsilyl)oxy)propyl Acetate (3CAa)

Yellow liquid. $[\alpha]_{\mathrm{D}}{ }^{20} 10.8\left(\mathrm{c}=1.0, \mathrm{CHCl}_{3}\right) .{ }^{1} \mathrm{H} \mathrm{NMR}\left(400 \mathrm{MHz}, \mathrm{CDCl}_{3}\right) \delta 7.37(\mathrm{~d}$, $J=7.2 \mathrm{~Hz}, 2 \mathrm{H}), 7.33-7.27(\mathrm{~m}, 2 \mathrm{H}), 7.23-7.19(\mathrm{~m}, 1 \mathrm{H}), 5.86-5.76(\mathrm{~m}, 1 \mathrm{H}), 5.24-5.10(\mathrm{~m}, 1 \mathrm{H})$, $5.05(\mathrm{dd}, J=10.1,1.7 \mathrm{~Hz}, 1 \mathrm{H}), 4.13(\mathrm{q}, J=6.8 \mathrm{~Hz}, 1 \mathrm{H}), 4.02(\mathrm{~d}, J=6.4 \mathrm{~Hz}, 2 \mathrm{H}), 3.72(\mathrm{dd}$, $J=10.3,5.5 \mathrm{~Hz}, 1 \mathrm{H}), 3.66(\mathrm{dd}, J=10.3,5.9 \mathrm{~Hz}, 1 \mathrm{H}), 3.34(\mathrm{~d}, J=6.1 \mathrm{~Hz}, 2 \mathrm{H}), 3.10(\mathrm{t}, J=5.9 \mathrm{~Hz}$, $1 \mathrm{H}), 1.98(\mathrm{~s}, 3 \mathrm{H}), 1.38(\mathrm{~d}, J=6.8 \mathrm{~Hz}, 3 \mathrm{H}), 0.88(\mathrm{~s}, 9 \mathrm{H}), 0.03(\mathrm{~d}, J=4.4 \mathrm{~Hz}, 6 \mathrm{H}) .{ }^{13} \mathrm{C} \mathrm{NMR}$ $\left(101 \mathrm{MHz} \mathrm{CDCl}_{3}\right) \delta 170.96,145.05,139.10,128.05,127.57,126.56,115.71,63.44,62.46,57.30$, $56.88,49.84,25.85,21.09,18.23,-5.54$. HRMS-ESI $(m / z):[\mathrm{M}+\mathrm{H}]^{+}$calcd for $\mathrm{C}_{22} \mathrm{H}_{38} \mathrm{NO}_{3} \mathrm{Si}$, 392.2563 , found 392.2565 .

\subsection{7. (R)-ethyl 3-acetoxy-2-(allyl((R)-1-phenylethyl)amino)propanoate (3DAa)}

Yellow liquid. $[\alpha]_{\mathrm{D}}{ }^{20} 18.9\left(\mathrm{c}=1.0, \mathrm{CHCl}_{3}\right) .{ }^{1} \mathrm{H} \mathrm{NMR}\left(400 \mathrm{MHz}, \mathrm{CDCl}_{3}\right) \delta 7.39-7.26$ $(\mathrm{m}, 4 \mathrm{H}), 7.25-7.18(\mathrm{~m}, 1 \mathrm{H}), 5.78(\mathrm{dd}, J=17.2,10.2 \mathrm{~Hz}, 1 \mathrm{H}), 5.15(\mathrm{dd}, J=17.2,1.8 \mathrm{~Hz}, 1 \mathrm{H})$, 5.12-5.05 (m, 2H), 4.21-4.12 (m, 2H), $4.00(\mathrm{q}, J=6.8 \mathrm{~Hz}, 1 \mathrm{H}), 3.12(\mathrm{~d}, J=6.4 \mathrm{~Hz}, 2 \mathrm{H}), 2.99$ $(\mathrm{dd}, J=14.1,4.5 \mathrm{~Hz}, 1 \mathrm{H}), 2.89(\mathrm{dd}, J=14.1,7.2 \mathrm{~Hz}, 1 \mathrm{H}), 2.10(\mathrm{~s}, 3 \mathrm{H}), 1.35(\mathrm{~d}, J=6.8 \mathrm{~Hz}, 3 \mathrm{H})$, $1.25(\mathrm{t}, J=7.1 \mathrm{~Hz}, 3 \mathrm{H}) .{ }^{13} \mathrm{C}$ NMR $\left(101 \mathrm{MHz}, \mathrm{CDCl}_{3}\right) \delta 170.15,169.28,143.05,136.27,127.88$, 127.56, 126.65, 116.98, 72.30, 61.05, 58.54, 53.69, 50.03, 20.60, 15.17, 13.95. HRMS-ESI $(\mathrm{m} / \mathrm{z})$ : $[\mathrm{M}+\mathrm{H}]^{+}$calcd for $\mathrm{C}_{18} \mathrm{H}_{26} \mathrm{NO}_{4}, 320.1812$, found 320.1815 .

\subsection{8. (R)-ethyl 2-(allyl((R)-1-phenylethyl)amino)-3-azidopropanoate (3DAb)}

Yellow liquid. $[\alpha]_{\mathrm{D}}{ }^{20} 24.8\left(\mathrm{c}=1.0, \mathrm{CHCl}_{3}\right) .{ }^{1} \mathrm{H} \mathrm{NMR}\left(400 \mathrm{MHz}, \mathrm{CDCl}_{3}\right) \delta 7.35-7.28(\mathrm{~m}$, $4 \mathrm{H}), 7.27-7.21(\mathrm{~m}, 1 \mathrm{H}), 5.79-5.71(\mathrm{~m}, 1 \mathrm{H}), 5.19-5.12(\mathrm{~m}, 1 \mathrm{H}), 5.10(\mathrm{dd}, J=10.1,1.5 \mathrm{~Hz}, 1 \mathrm{H})$, 4.38-4.20 (m, 2H), $4.18(\mathrm{dd}, J=10.1,5.4 \mathrm{~Hz}, 1 \mathrm{H}), 3.95(\mathrm{q}, J=6.9 \mathrm{~Hz}, 1 \mathrm{H}), 3.27(\mathrm{dd}, J=13.6$, $10.1 \mathrm{~Hz}, 1 \mathrm{H}), 3.05(\mathrm{t}, J=6.0 \mathrm{~Hz}, 2 \mathrm{H}), 2.78(\mathrm{dd}, J=13.6,5.4 \mathrm{~Hz}, 1 \mathrm{H}), 1.37(\mathrm{~d}, J=6.9 \mathrm{~Hz}, 3 \mathrm{H})$, $1.32(\mathrm{t}, J=7.1 \mathrm{~Hz}, 3 \mathrm{H}) .{ }^{13} \mathrm{C}$ NMR $\left(101 \mathrm{MHz}, \mathrm{CDCl}_{3}\right) \delta 169.67,142.48,136.55,128.17,127.71$, $127.02,117.33,61.83,59.90,55.18,54.68,54.59,54.41,16.01,14.14$. HRMS-ESI $(m / z):[M+$ $\mathrm{H}]^{+}$calcd for $\mathrm{C}_{16} \mathrm{H}_{23} \mathrm{~N}_{4} \mathrm{O}_{2}, 303.1714$, found 303.1716 .

\subsection{9. (R)-2-(allyl((R)-1-phenylethyl)amino)-3-(allyloxy)-3-methylbutyl acetate (12)}

To a stirred solution of (R)-2-(2-(allyloxy)propan-2-yl)-1-((R)-1-phenylethyl)aziridine (11) $(0.858 \mathrm{~g}, 3.951 \mathrm{mmol})$ in dry $\mathrm{CH}_{3} \mathrm{CN}(13.17 \mathrm{~mL})$ was added silver trifluoromethanesulfonate $(1.116 \mathrm{~g}, 4.346 \mathrm{mmol})$ and allyl iodide $(0.405 \mathrm{~mL}, 4.346 \mathrm{mmol})$ under $\mathrm{N}_{2}$ at $0{ }^{\circ} \mathrm{C}$. After 5-10 min, NaOAc $(0.356 \mathrm{~g}, 4.346 \mathrm{mmol})$ was added to the solution. After $10 \mathrm{~min}$, the solution was allowed to be warmed to RT and was stirred for $3 \mathrm{~h}$. After quenching by adding water $(10 \mathrm{~mL})$, the reaction product was extracted with $\mathrm{CH}_{2} \mathrm{Cl}_{2}(20 \mathrm{~mL})$ three times. It was then dried over anhydrous MgSO4, filtered and concentrated in vacuo. The reaction product was purified by column chromatography $(1: 9=$ EtOAc:Hex $)$ to provide an analytically pure product $12(0.525 \mathrm{~g}, 71 \%)$. Yellow liquid. $[\alpha]_{\mathrm{D}}{ }^{20} 17.6\left(\mathrm{c}=1.0, \mathrm{CHCl}_{3}\right)$. ${ }^{1} \mathrm{H} \mathrm{NMR}\left(400 \mathrm{MHz}, \mathrm{CDCl}_{3}\right) \delta{ }^{1} \mathrm{H} \mathrm{NMR}\left(400 \mathrm{MHz}, \mathrm{CDCl}_{3}\right) \delta 7.36-7.24(\mathrm{~m}, 4 \mathrm{H}), 7.23-7.16$ $(\mathrm{m}, 1 \mathrm{H}), 5.97-5.75(\mathrm{~m}, 2 \mathrm{H}), 5.17(\mathrm{dq}, J=17.2,1.8 \mathrm{~Hz}, 1 \mathrm{H}), 5.12-5.00(\mathrm{~m}, 3 \mathrm{H}), 4.57(\mathrm{dd}$, $J=11.9,4.3 \mathrm{~Hz}, 1 \mathrm{H}), 4.37(\mathrm{dd}, J=11.9,7.1 \mathrm{~Hz}, 1 \mathrm{H}), 4.29(\mathrm{q}, J=6.9 \mathrm{~Hz}, 1 \mathrm{H}), 3.79(\mathrm{dt}, J=5.0$, $1.6 \mathrm{~Hz}, 2 \mathrm{H}), 3.52(\mathrm{ddt}, J=14.6,4.7,1.6 \mathrm{~Hz}, 1 \mathrm{H}), 3.40(\mathrm{dd}, J=14.6,8.1 \mathrm{~Hz}, 1 \mathrm{H}), 2.96(\mathrm{dd}$, $J=7.1,4.3 \mathrm{~Hz}, 1 \mathrm{H}), 2.08(\mathrm{~s}, 3 \mathrm{H}), 1.36(\mathrm{~d}, J=6.9 \mathrm{~Hz}, 3 \mathrm{H}), 1.02(\mathrm{~s}, 3 \mathrm{H}), 0.98(\mathrm{~s}, 3 \mathrm{H}) .{ }^{13} \mathrm{C}$ NMR $\left(101 \mathrm{MHz} \mathrm{CDCl}_{3}\right) \delta 170.96,144.49,138.91,134.71,128.05,127.53,126.64,116.60,115.71$, 71.90, 69.40, 63.84, 57.73, 55.19, 49.61, 21.07, 18.73. HRMS-ESI $(m / z)$ : $[\mathrm{M}+\mathrm{H}]^{+}$calcd for $\mathrm{C}_{21} \mathrm{H}_{32} \mathrm{NO}_{3}, 346.2373$, found 346.2375. 
3.20. ((R,Z)-2,2-dimethyl-4-((R)-1-phenylethyl)-3,4,5,8-tetrahydro-2H-1,4-oxazocin-3-yl)methyl Acetate (13)

To a solution of $(R)-2-($ allyl $((R)-1-$ phenylethyl)amino)-3-(allyloxy)-3-methylbutyl acetate (12) $(0.150 \mathrm{~g}, 0.473 \mathrm{mmol})$ in $\mathrm{CH}_{2} \mathrm{Cl}_{2}(120 \mathrm{~mL})$ was added benzylidene-bis(tricyclohexylphosphine)dichlororuthenium $(0.039 \mathrm{~g}, 0.048 \mathrm{mmol})$. The reaction mixture was then stirred at reflux for $8 \mathrm{~h}$. After completion of the reaction (monitored by TLC), solvent was evaporated under reduced pressure. Purification of the crude residue by silica gel column chromatography (ethyl acetate:hexane $=1: 9)$ afforded $13(71 \mathrm{mg}, 76 \%)$. Yellow liquid. $[\alpha]_{\mathrm{D}}{ }^{20}-3.5\left(\mathrm{c}=1.0, \mathrm{CHCl}_{3}\right) .{ }^{1} \mathrm{H}$ NMR $\left(400 \mathrm{MHz}, \mathrm{CDCl}_{3}\right) \delta 7.35-7.28(\mathrm{~m}, 4 \mathrm{H}), 7.24-7.20$ $(\mathrm{m}, 1 \mathrm{H}), 5.60-5.47(\mathrm{~m}, 1 \mathrm{H}), 5.45-5.33(\mathrm{~m}, 1 \mathrm{H}), 4.51-4.45(\mathrm{~m}, 2 \mathrm{H}), 4.26(\mathrm{dd}, J=12.2,6.9 \mathrm{~Hz}$, $1 \mathrm{H}), 4.14-4.05(\mathrm{~m}, 1 \mathrm{H}), 4.01(\mathrm{q}, J=6.8 \mathrm{~Hz}, 1 \mathrm{H}), 3.66(\mathrm{dd}, J=16.2,6.3 \mathrm{~Hz}, 1 \mathrm{H}), 3.10-3.04(\mathrm{~m}$, 2H), $1.86(\mathrm{~s}, 3 \mathrm{H}), 1.46(\mathrm{~s}, 3 \mathrm{H}), 1.38(\mathrm{~d}, J=6.8 \mathrm{~Hz}, 3 \mathrm{H}), 1.24(\mathrm{~s}, 3 \mathrm{H}) .{ }^{13} \mathrm{C} \mathrm{NMR}(101 \mathrm{MHz}$, $\left.\mathrm{CDCl}_{3}\right) \delta 170.84,145.02,129.91,129.50,128.00,127.73,126.66,77.99,63.73,62.89,62.56,61.73$, $43.80,27.60,24.37,20.88,20.48$. HRMS-ESI $(m / z):[\mathrm{M}+\mathrm{H}]^{+}$calcd for $\mathrm{C}_{19} \mathrm{H}_{28} \mathrm{NO}_{3}, 318.2014$, found 318.2017 .

\subsection{1. (R)-tert-butyl 3-(acetoxymethyl)-2,2-dimethyl-1,4-oxazocane-4-carboxylate (14)}

To a stirred solution of ((R,Z)-2,2-dimethyl-4- $((R)-1$-phenylethyl)-3,4,5,8-tetrahydro2H-1,4-oxazocin -3-yl)methyl acetate (13) (306 mg, $0.965 \mathrm{mmol}$ ) in $\mathrm{MeOH}(9.65 \mathrm{~mL})$ was added $\mathrm{Pd}(\mathrm{OH})_{2}(634 \mathrm{mg}, 1.158 \mathrm{mmol}, 50 \% \mathrm{wet})$ and the resultant reaction mixture was stirred at RT under atmospheric power of $\mathrm{H}_{2}$ gas. After $30 \mathrm{~min},(\mathrm{Boc})_{2} \mathrm{O}(421 \mathrm{mg}, 1.929 \mathrm{mmol})$ was added to the reaction flask at RT. The reaction mixture was stirred for $1.0 \mathrm{~h}$, filtered with $\mathrm{MeOH}$, and concentrated in vacuo and purified by silica gel chromatography to get the desired product $14(215 \mathrm{mg}, 71 \%)$. Yellow liquid. ${ }^{1} \mathrm{H} \mathrm{NMR}\left(400 \mathrm{MHz}, \mathrm{CDCl}_{3}\right) \delta 4.82(\mathrm{~d}$, $J=9.7 \mathrm{~Hz}, 1 \mathrm{H}), 4.34(\mathrm{dd}, J=11.2,4.0 \mathrm{~Hz}, 1 \mathrm{H}), 4.09(\mathrm{t}, J=10.1 \mathrm{~Hz}, 1 \mathrm{H}), 3.85-3.79(\mathrm{~m}, 1 \mathrm{H})$, 3.33-3.29 (m, 2H), $2.05(\mathrm{~d}, J=3.6 \mathrm{~Hz}, 3 \mathrm{H}), 1.64(\mathrm{~s}, 1 \mathrm{H}), 1.45(\mathrm{~s}, 9 \mathrm{H}), 1.36-1.30(\mathrm{~m}, 3 \mathrm{H}), 1.22$ (s, 3H), 1.18 (s, 3H). ${ }^{13} \mathrm{C}$ NMR $\left(101 \mathrm{MHz}, \mathrm{CDCl}_{3}\right) \delta 170.84,152.05,79.93,77.99,70.12,63.18$, $53.74,43.80,28.59,27.60,25.91,24.37,20.88,20.42$. HRMS-ESI $(m / z):[\mathrm{M}+\mathrm{H}]^{+}$calcd for $\mathrm{C}_{16} \mathrm{H}_{30} \mathrm{NO}_{5}, 316.2034$, found 316.2037.

\section{Conclusions}

In conclusion, the highly strained three-membered aziridine ring is successfully activated as the aziridinium ion through alkylation of the ring nitrogen, including with methyl, ethyl and allyl groups, followed by ring opening with nucleophiles such as acetate and azide. This so-called $N$-alkylative aziridine ring opening may provide an easy route for the synthesis of various $N$-alkylated amine-containing molecules with concomitant introduction of an external nucleophile at either its $\alpha$ - or $\beta$-position.

Supplementary Materials: All analytical data of compounds other than the representative example are reported along the copies of ${ }^{1} \mathrm{H}$ and ${ }^{13} \mathrm{C}$ NMR spectra.

Author Contributions: Conceptualization, H.-J.H. and J.C.; methodology, J.C. and T.Y.; investigation, H.-J.H., J.C. and T.Y.; experiments and data curation, J.C. and T.Y.; writing-original draft preparation, H.-J.H.; writing-review and editing, H.-J.H. and T.Y.; supervision, H.-J.H.; project administration, H.-J.H.; funding acquisition, H.-J.H. All authors have read and agreed to the published version of the manuscript.

Funding: This research was supported by the National Research Foundation of Korea (NRF2012M3A7B4049645 and 2021R1A5A6002803 with the Centre for New Directions in Organic Synthesis). Additional financial support from 2020R1A2C1007102 and HUFS Grant 2021 (for the preparation of this manuscript) are also appreciated.

Data Availability Statement: The data presented in this study are available on request from the corresponding author.

Acknowledgments: Authors thanks to Jala Ranjith for his help to preparing this manuscript.

Conflicts of Interest: The authors declare no conflict of interest. 
Sample Availability: Samples of the compounds in this paper are available on your request from the authors.

\section{References}

1. Tanner, D. Chiral Aziridines-Their Synthesis and Use in Stereoselective Transformations. Angew. Chem. Int. Ed. Eng. 1994, 33, 599-619. [CrossRef]

2. Zwanenburg, B.; ten Holte, P. The Synthetic Potential of Three-Membered Ring Aza-Heterocycles. Top. Curr. Chem. 2001, 216, 93-124. [CrossRef]

3. Sweeney, J.B. Aziridines: Epoxides' ugly cousins? Chem. Soc. Rev. 2002, 31, 247-258. [CrossRef] [PubMed]

4. Hu, X.E. Nucleophilic ring opening of aziridines. Tetrahedron 2004, 60, 2701-2743. [CrossRef]

5. McCoull, W.; Davis, F.A. Recent Synthetic Applications of Chiral Aziridines. Synthesis 2000, 2000, 1347-1365. [CrossRef]

6. Watson, I.D.G.; Yu, L.; Yudin, A.K. Advances in Nitrogen Transfer Reactions Involving Aziridines. Acc. Chem. Res. 2006, 39, 194-206. [CrossRef]

7. Padwa, A.; Murphree, S.S. Epoxides and aziridines-A mini review. Arkivoc 2006, 3, 6-33.

8. Singh, G.S.; D'Hooghe, M.; De Kimpe, N. Synthesis and Reactivity of C-Heteroatom-Substituted Aziridines. Chem. Rev. 2007, 107, 2080-2135. [CrossRef]

9. Ha, H.-J.; Jung, J.-H.; Lee, W.K. Application of Regio- and Stereoselective Functional Group Transformation of Chiral Aziri-dine2-carboxylate. Asian J. Org. Chem. 2014, 3, 1020-1035. [CrossRef]

10. D'hooghe, M.; Ha, H.-J. (Eds.) Synthesis of 4- to 7-Membered Heterocycles by Ring Expansion; Springer: Berlin/Heidelberg, Germany, 2016.

11. Akhtar, R.; Naqvi, S.A.R.; Zahoor, A.F.; Saleem, S. Nucleophilic ring opening reactions of aziridines. Mol. Divers. 2018, $22,447-501$. [CrossRef]

12. D'Hooghe, M.; Ha, H.-J.; Macha, L. Deployment of Aziridines for the Synthesis of Alkaloids and Their Derivatives. Synthesis 2019, 51, 1491-1515. [CrossRef]

13. Cherni, E.; Essalah, K.; Besbes, N.; Abderrabba, M.; Ayadi, S. Theoretical investigation of the regioselective ring opening of 2-methylaziridine. Lewis acid effect. J. Mol. Model. 2018, 24, 309. [CrossRef] [PubMed]

14. Baruah, B.; Deuri, S.; Phukan, P. Reactivity and regioselectivity in the ring opening of 2-substituted non-activated aziridines: A density functional theory based analysis. Comput. Theor. Chem. 2014, 1027, 197-202. [CrossRef]

15. Luginina, J.; Turks, M. Non-activated aziridines as building blocks for the synthesis of aza-heterocycles. Chem. Heterocycl. Compd. 2016, 52, 773-775. [CrossRef]

16. Pitzer, K.S. Strain energies of cyclic hydrocarbons. Science 1945, 101, 672. [CrossRef]

17. Lewis, L.L.; Turner, L.L.; Salter, E.A.; Magers, D.H. Computation of the conventional strain energy in oxaziridine. J. Mol. Struct. THEOCHEM 2002, 592, 161-171. [CrossRef]

18. Dudev, T.; Lim, C. Ring Strain Energies from ab Initio Calculations. J. Am. Chem. Soc. 1998, 120, 4450-4458. [CrossRef]

19. Morgan, K.M.; Ellis, J.A.; Lee, J.; Fulton, A.; Wilson, S.L.; Dupart, P.S.; Dastoori, R. Thermochemical Studies of Epoxides and Related Compounds. J. Org. Chem. 2013, 78, 4303-4311. [CrossRef]

20. Lee, K.-D.; Suh, J.-M.; Park, J.-H.; Ha, H.-J.; Choi, W.G.; Park, C.S.; Lee, W.K.; Dong, Y.; Yun, H. New synthesis and ring opening of cis-3-alkylaziridine-2-carboxylates. Tetrahedron 2001, 57, 8267-8276. [CrossRef]

21. Sin, T.B.; Kang, S.H.; Lee, K.S.; Lee, W.K.; Yun, H.; Dong, Y.; Ha, H.-J. A Novel Synthesis of 5-Functionalized Oxazolidin-2-ones from Enantiomerically Pure 2-Substituted $N-[(R)-(+)-\alpha$-Methylbenzyl]aziridines. J. Org. Chem. 2003, 68, $104-108$.

22. Kim, Y.; Ha, H.-J.; Yun, H.; Lee, B.K.; Lee, W.K. Ring opening of 2-acylaziridines by acid chlorides. Tetrahedron 2006, 62, 8844-8849. [CrossRef]

23. Eum, H.; Choi, J.; Cho, C.G.; Ha, H.J. Regiochemistry-Directed Syntheses of Polyhydroxylated Alkaloids from Chiral Aziridines. Asian J. Org. Chem. 2015, 4, 1399-1409. [CrossRef]

24. Catak, S.; D’hooghe, M.; Verstraelen, T.; Hemelsoet, K.; Van Nieuwenhove, A.; Ha, H.-J.; Waroquier, M.; Van Speybroeck, V.; De Kimpe, N. Opposite Regiospecific Ring-opening of 2-(Cyanomethyl)aziridines by Hydrogen Bromide and Benzyl Bromide: Experimental Study and Theoretical Rationalization. J. Org. Chem. 2010, 75, 4530-4541. [CrossRef]

25. Chen, Y.; Sun, X.; Wu, N.; Li, J.; Jin, S.; Zhong, Y.; Liu, Z.; Rogachev, A.; Chong, H.-S. Synthetic and theoretical investigation on the one-pot halogenation of $\beta$-amino alcohols and nucleophilic ring opening of aziridinium ions. Org. Biomol. Chem. 2016, 14, 920-939. [CrossRef]

26. Choi, J.; Yadav, N.N.; Ha, H. Preparation of a Stable Bicyclic Aziridinium Ion and Its Ring Expansion toward Piperidines and Azepanes. Asian J. Org. Chem. 2017, 6, 1292-1307. [CrossRef]

27. Stankovic, S.; D’Hooghe, M.; Catak, S.; Eum, H.; Waroquier, M.; Van Speybroeck, V.; De Kimpe, N.; Ha, H.-J. Regioselectivity in the ring opening of non-activated aziridines. Chem. Soc. Rev. 2012, 41, 643-665. [CrossRef]

28. D'Hooghe, M.; Catak, S.; Stankovic, S.; Waroquier, M.; Kim, Y.; Ha, H.-J.; Van Speybroeck, V.; De Kimpe, N. Systematic Study of Halide-Induced Ring Opening of 2-Substituted Aziridinium Salts and Theoretical Rationalization of the Reaction Pathways. Eur. J. Org. Chem. 2010, 25, 4920-4931. [CrossRef]

29. Arico, F.; Aldoshin, A.S.; Musolino, M.; Crisma, M.; Tundo, P. $\beta$-Aminocarbonates in Regioselective and Ring Expansion Reactions. J. Org. Chem. 2018, 83, 236-243. [CrossRef] [PubMed] 
30. Cochi, A.; Pardo, D.G.; Cossy, J. Access to Optically Active 3-Aminopiperidines by Ring Expansion of Prolinols: Thermody-namic versus Kinetic Control. Eur. J. Org. Chem. 2012, 10, 2023-2040. [CrossRef]

31. Yun, S.Y.; Catak, S.; Lee, W.K.; D’hooghe, M.; De Kimpe, N.; Van Speybroeck, V.; Waroquier, M.; Kim, Y.; Ha, H.-J. Nucle-ophiledependent regioselective ring opening of 2-substituted $N, N$-dibenzylaziridinium ions: Bromide versus hydride. Chem. Commun. 2009, 18, 2508-2510. [CrossRef] [PubMed]

32. Kim, Y.; Ha, H.-J.; Yun, S.Y.; Lee, W.K. Preparation of Stable Aziridinium Ions and Their Ring Openings. Chem. Commun. 2008, 4363-4365. [CrossRef]

33. Kim, Y.; Yoon, D.-H.; Ha, H.-J.; Kang, K.Y.; Lee, W.K. N-Methylative aziridine ring opening and asymmetric synthesis of MeBmt. Tetrahedron Lett. 2011, 52, 5918-5920. [CrossRef]

34. Yoon, D.-H.; Kang, P.; Lee, W.K.; Kim, Y.; Ha, H.-J. Alkylative Ring Opening of N-Methylaziridinium Ions and a Formal Synthesis of Tyroscherin. Org. Lett. 2012, 14, 429-431. [CrossRef]

35. Yoon, D.-H.; Ji, M.-K.; Ha, H.-J.; Park, J.; Kang, P.; Lee, W.K. Synthesis and Biological Activities of Tyroscherin Analogs. Bull. Korean Chem. Soc. 2013, 34, 1899-1902. [CrossRef]

36. Lee, J.; Lee, J.E.; Ha, H.-J.; Son, S.I.; Lee, W.K. N-Methylative aziridine ring opening: Asymmetric synthesis of hygroline, pseudohygroline, and hygrine. Tetrahedron Lett. 2015, 56, 856-858. [CrossRef]

37. Jung, J.; Kim, S.; Eum, H.; Lee, W.K.; Ha, H.J. N-methylative aziridine ring opening and the synthesis of (S)-3-methylamino-3-[(R)pyrrolidin-3-yl]propanenitrile. Tetrahedron 2017, 73, 5993-5999. [CrossRef]

38. Nicolaou, K.C.; Ogawa, Y.; Zuccarello, G.; Schweiger, E.J.; Kumazawa, T. Cyclic conjugated enediynes related to calicheami-cins and esperamicins: Calculations, synthesis, and properties. J. Am. Chem. Soc. 1988, 14, 4866-4868. [CrossRef]

39. Ha, H.-J.; Yoon, D.-H.; Kang, L.-S.; Hong, M.C.; Lee, W.K. Synthesis of D-erythro-Sphingosine from D-ribo-Phytosphingosine. Bull. Korean Chem. Soc. 2009, 30, 535-536. [CrossRef]

40. Park, C.S.; Kim, M.S.; Sim, T.B.; Pyun, D.K.; Lee, C.H.; Choi, D.; Lee, W.K.; Chang, J.-W.; Ha, H.-J. Novel Stereoselective Synthesis of Functionalized Oxazolidinone from Chiral Aziridines. J. Org. Chem. 2003, 68, 43-49. [CrossRef]

41. Kazakova, A.N.; Vasilyev, A.V. Trifluoromethanesulfonic acid in organic synthesis. Zhurnal Org. Khimii 2017, 53, 479-502. [CrossRef] 